\title{
Mechanizm różnicowy $z$ tarciem wewnętrznym jako niezbędny czynnik podniesienia efektywności trakcyjnej napędu tramwaju w łukach toru
}

\begin{abstract}
Przedmiotem opracowania jest technicznie zmodyfikowana wersja uktadu napędowego AdTranz (wedtug rysunków 1 i 2), tramwaju niskopodtogowego, zapewniajacego efektywne wywiqzywanie sit trakcyjnych w tukach toru o małym promieniu krzywizny.
\end{abstract}

\section{Wprowadzenie}

W układzie napędowym tramwaju występują ekstremalnie trudne warunki trakcyjne, gdy pojazd ma ruszyć w huku toru znajdującym się na wzniesieniu. Pomiędzy racjonalnymi technicznymi warunkami budowy napędnego zestawu kół przeznaczonego dla tramwaju o wysokiej efektywności trakcyjnej w ruchu zarówno $\mathrm{w}$ torze prostym jak też w łukach toru o małym promieniu krzywizny występuje immanentna sprzeczność. Efektywne wywiązywanie sił trakcyjnych na kołach napędnych w łukach o małym promieniu wymaga albo niezależnego napędu osi kół lewego i prawego (dwoma silnikami elektrycznymi) albo zastosowania mechanizmu różnicowego pomiędzy 'półosiami' umownego zestawu. Pojawiło się wiele takich rozwiązań, które jednak charakteryzują się złą dynamiką ruchu $\mathrm{w}$ torze prostym, dużymi wartościami kątów nabiegania kół na szynę i nadmiernymi zużyciami obrzeży kół. Kompromisowym rozwiązaniem technicznym może być zmodyfikowany układ napędu (na przykład typu AdTranz) z mechanizmem różnicowym o odpowiednio dobranym momencie tarcia wewnętrznego pomiędzy półosiami $[1,3]$. Taki 'zestaw', dzięki odpowiednio dobranej nieczułości różnicowej mechanizmu różnicowego, może dobrze spełniać wymagania trakcyjne $\mathrm{w}$ torze prostym, zaś $\mathrm{w}$ łuku zapewnić należytą efektywność trakcyjną.

Siły trakcyjne $\mathrm{F}$ (podłużne) na obwodzie obydwóch kół zestawu, lewego „L” i prawego „P”, należy traktować jako ogólnie niejednakowe. W pracy [1] wprowadzono pojęcie współczynnika efektywności trakcyjnej zestawu $\mathrm{E}_{\mathrm{TZ}}$, będącego wyróżnikiem konstrukcyjnej przydatności układu napędowego tramwaju do pracy w łuku torowym.

Współczynnik $\mathrm{E}_{\mathrm{TZ}}$ wyraża się wzorem:

$$
E_{T Z}=1-\frac{\left|F_{L}-F_{P}\right|}{\left|F_{L}\right|+\left|F_{P}\right|}
$$

Maksymalny potencjał trakcyjnych sił (przyczepności) na obwodzie kół zestawu opisuje zależność $F_{z \max }=\left|F_{\text {Lmax }}\right|+\left|F_{P_{\max }}\right|$. Jednak pod względem konstrukcyjnym z pełną efektywnością trakcyjną, wyra- żoną wartością $\mathrm{E}_{\mathrm{TZ}}=1$ według (1), można mieć do czynienia niezależnie od stopnia wykorzystania maksymalnego potencjału sił trakcyjnych. Zauważmy, że według (1) efektywność trakcyjna $\mathrm{E}_{\mathrm{TZ}}=0,5$ wystapi, gdy trakcyjnie pracuje tylko jedno koło zestawu. Wartość $\mathrm{E}_{\mathrm{TZ}}$ spada drastycznie, gdy na jednym z kół występuje pasożytnicza siła ujemna. Właśnie taki przypadek przy klasycznym zestawie może wystapić w łuku toru. W przypadku, gdy trakcyjnie pracują dwa koła zestawu w zgodnym kierunku, lecz jedno z nich wykorzystuje jedynie $50 \%$ swej siły przyczepności, wtedy otrzymamy $E_{T Z}=1-\frac{1}{2} \cdot 0,5=0,75$. Wyznaczenie odpowiedniej (pod względem dynamicznym a zarazem trybologicznym) wartości momentu nieczułości różnicowej mechanizmu różnicowego stanowi oddzielne, złożone zadanie teoretyczno - doświadczalne.

\section{Różnicowy mechanizm napędowy AdTranz [3]}

$\mathrm{W}$ dalszym ciagu niniejszego artykułu ograniczono się do przedstawienia fundamentalnych zasad modyfikacji znanego rozwiązania AdTranz oraz do przedstawienia podstaw teoretycznych dla tego technicznego udoskonalenia.

„Klasyczny” napęd kół tramwajowych AdTranz (według rysunków 1 i 2) zawiera oryginalny mechanizm różnicowy $\mathrm{z}$ satelitami walcowymi. W torze prostym ten mechanizm charakteryzuje się nieznacznym, płynnym 'tarciem' wewnętrznym o charakterze wiskotycznym, a wartość momentu napędowego na obydwóch kołach pozostaje dobrze wyrównana, niezależnie od wartości promienia krzywizny toru. Zatem w torze zakrzywionym może wystąpić jedynie bardzo niewielka różnica momentów na kołach („L” i „P”), lecz obydwa te momenty, jakkolwiek nieznacznie różne pod względem wartości modułów, zawsze mają zwrot skierowany w jednym, zgodnym kierunku. Zatem jest to rozwiązanie bardzo dobre dla ruchu w tuku toru o małym promieniu, lecz w torze prostym funkcja prowadzenia zestawu $\mathrm{w}$ torze za pomocą sił podłużnych nie jest zagwarantowana. 
Mechaniczny układ napędu ma strukturę niemal samochodową, jak przy napędzie 'tylnego mostu' ciężarówki ze zwolnicami. Zastosowano planetarny mechanizm różnicowy [3], co oznacza, że koło talerzowe przekładni stożkowej jest osadzone na koszu satelitów walcowych.

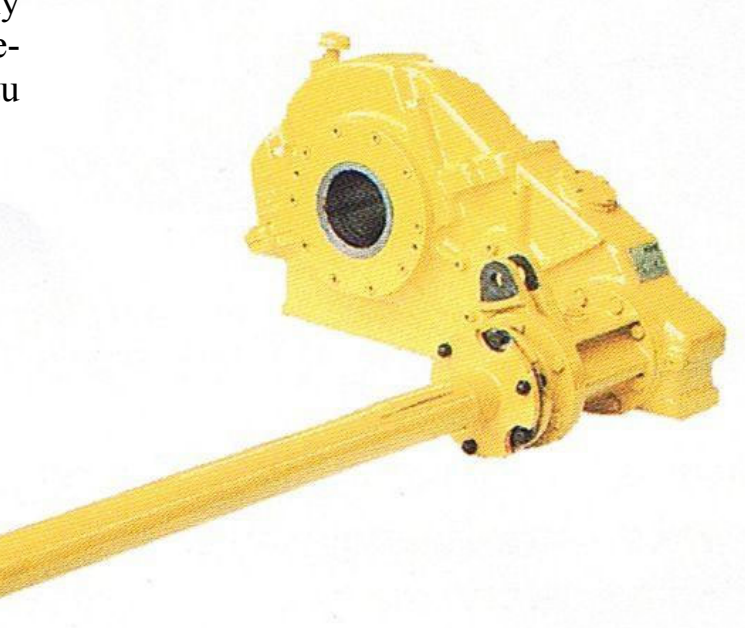

Rys. 1. Według [3] widok zewnętrzny napędu kół tramwajowych z zastosowaniem mechanizmu różnicowego AdTranz z satelitami walcowymi.
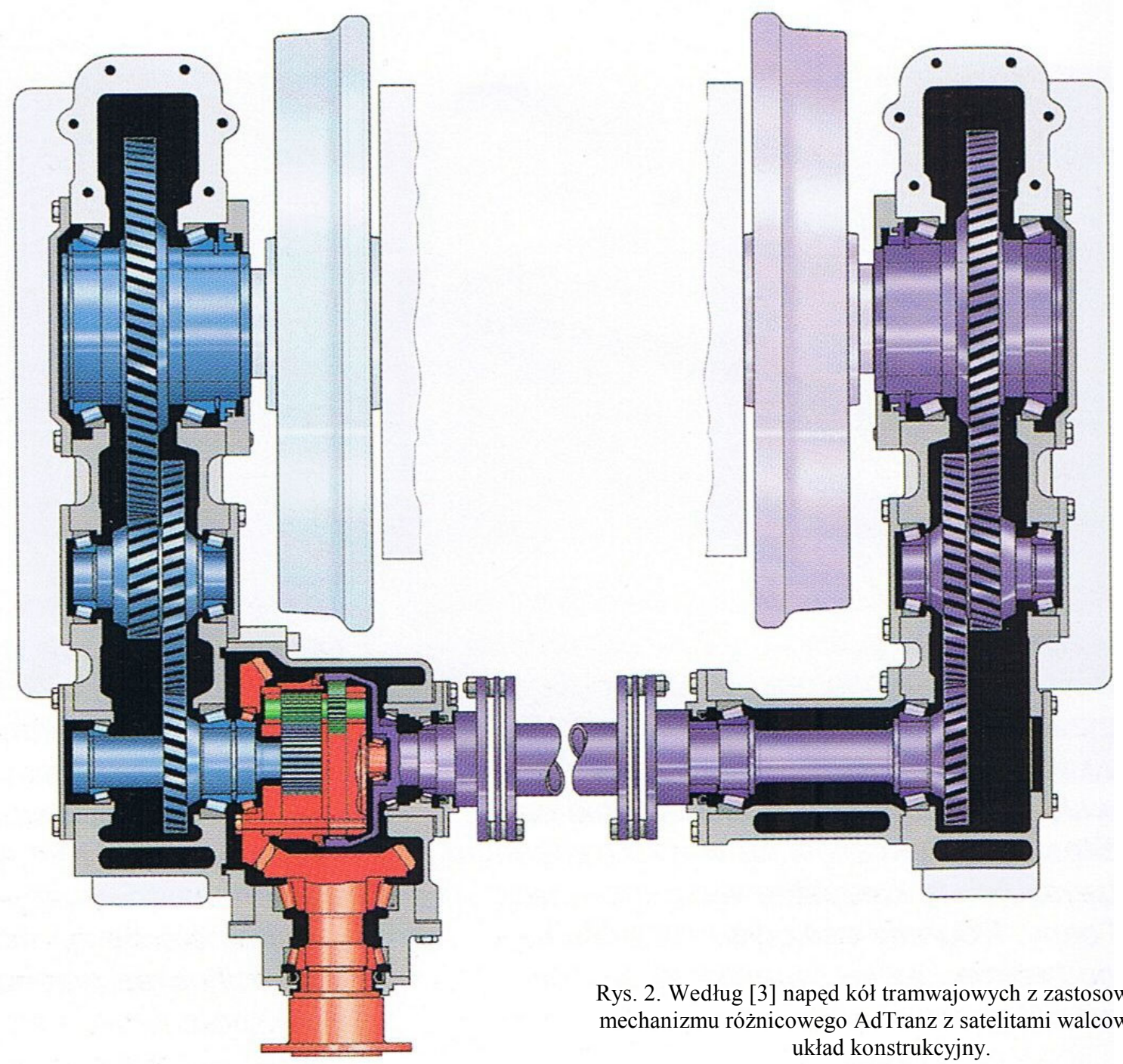

Rys. 2. Według [3] napęd kół tramwajowych z zastosowaniem mechanizmu różnicowego AdTranz z satelitami walcowymi układ konstrukcyjny. 
W tym miejscu pojawia się pytanie inżynierskie, jaka powinna być wartość i charakterystyka momentu autentycznie sprzęgającego koła zestawu „na sztywno", aby w torze prostym oraz w łukach o promieniu nie mniejszym od wartości granicznej $\rho_{g r}$, zestaw poprawnie spełniał swoje zdanie konturu adhezyjno prowadzącego. Wartość graniczną $\rho_{g r}$ została ściśle zdefiniowana w pracy [1].

Znalezienie odpowiedzi na powyższe pytanie wymaga indywidualnego badania dynamiki napędu ( $\mathrm{z}$ probabilistycznym uwzględnieniem topografii linii tramwajowej), przy niezbędnym udziale badań eksperymentalnych, podczas ruchu kompletnego pojazdu w torze.

W odniesieniu do osi kół jezdnych (a nie do półosi mechanizmu różnicowego) jest rzeczą oczywista, że moment autentycznego tarcia wewnętrznego w mechanizmie różnicowym powinien być odpowiednio dobrany (przeliczony) stosownie do wartości przełożenia zastosowanej redukcyjnej przekładni zębatej.

Naukowo - techniczne zagadnienie odpowiedniego doboru momentu tarcia wewnętrznego w mechanizmie różnicowym zostało (na technicznym stopniu ogólności) omówione w monografii [2]. W dalszym ciagu, na rysunku 5, pokazano dwa przykładowe warianty technicznych rozwiązań klasycznego mechanizmu różnicowego z kołami stożkowymi.
Zgodnie $\mathrm{z}$ rysunkiem 3, oraz materiałem zawartym $\mathrm{w}$ monografii [2], promienie podziałowe poszczególnych kół zębatych wynoszą odpowiednio:

$$
r_{c}=\frac{1}{2} m \cdot Z_{c} ; \quad r_{K}=\frac{1}{2} m \cdot Z_{k} ; \quad r_{s 1}=\frac{1}{2} m \cdot Z_{s 1} ; \quad r_{s 2}=\frac{1}{2} m \cdot Z_{s 2} ;
$$

przy czym:

$$
r_{b}=r_{c}+r_{s 1} ; \quad r_{K}=r_{c}+r_{s 1}+r_{s 2}
$$

W przypadku wyidealizowanym, czyli przy doskonałej sprawności zazębień i dobrym smarowaniu przekładni, bilans momentów obrotowych jest następujacy:

$$
\Sigma \vec{M}_{i}=0 ; \quad M_{c}+M_{k}=M_{b}
$$

Równowaga obrotowa pojedynczego satelity wymaga spełnienia bilansu sił obwodowych na jego obydwóch kołach, opisanego pierwszym z równań (4), zaś wyrównane wartości momentów w półosiach otrzymamy, gdy spełnione jest drugie równanie (4).

$$
r_{s 1} \cdot F_{s 1}=r_{s 2} \cdot F_{s 2} ; \quad r_{c} \cdot F_{s 1}=r_{K} \cdot F_{s 2} ;
$$

Przy założeniu jednakowych modułów m uzębienia wszystkich walcowych kół omawianej przekładni planetarno różnicowej, z zależności (5) wynika elementarna zasada budowy planetarnego mechanizmu różnicowego:

$$
\frac{r_{s 1}}{r_{s 2}}=\frac{r_{c}}{r_{k}} \quad \text { albo: }: \frac{Z_{s 1}}{Z_{s 2}}=\frac{Z_{c}}{Z_{K}}
$$

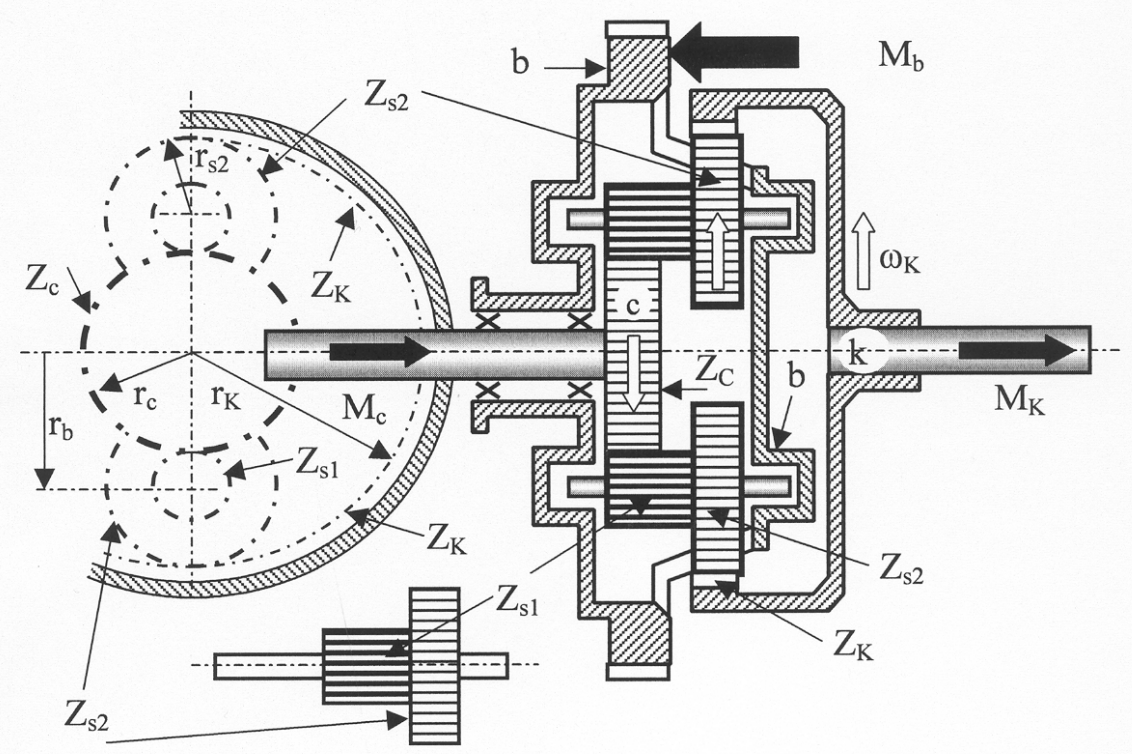

albo, po uwzględnieniu (2) i (3):

$$
\frac{Z_{s 1}}{Z_{s 2}}=\frac{Z_{c}}{Z_{c}+Z_{s 1}+Z_{s 2}}
$$

co prowadzi do fundamentalnej formuły algebraicznej określającej zasadę budowy satelitów oraz całego mechanizmu (wraz z równiami 3).

$$
\frac{Z_{s 1}}{Z_{c}}=\frac{Z_{s 2}-Z_{s 1}}{Z_{s 2}+Z_{s 1}}
$$

Rys. 3. Schemat przekładni planetarno - różnicowej AdTranz.

Kosz satelitów b - (,,basket”) jest elementem aktywnym (napędzającym). Koła K (,koronowe”) oraz c (,centralne”) są osadzone na elementach biernych, (czyli na półosiach). Białymi strzałkami zaznaczono kierunek obrotów elementów biernych $\mathbf{k}$ oraz $\mathbf{c}$, gdy element aktywny b został unieruchomiony.
Poprawna budowa oraz montaż mechanizmu są możliwe jedynie przy zachowaniu (niezbywalnego we wszystkich przekładniach planetarnych [2]) warunku biegunowo równomiernego rozmieszczenia satelitów, albowiem musimy mieć na względzie techniczną możliwość poprawnego zmontowania oraz starannego wyrównoważenia przekładni planetarnej. Satelity muszą być odpowiednio oznaczone w miejscu wierzchołkowej zgodności zębów koła $Z_{\mathrm{s} 1}$ i $Z_{\mathrm{s} 2}$ według rysunków 3 i 4. 


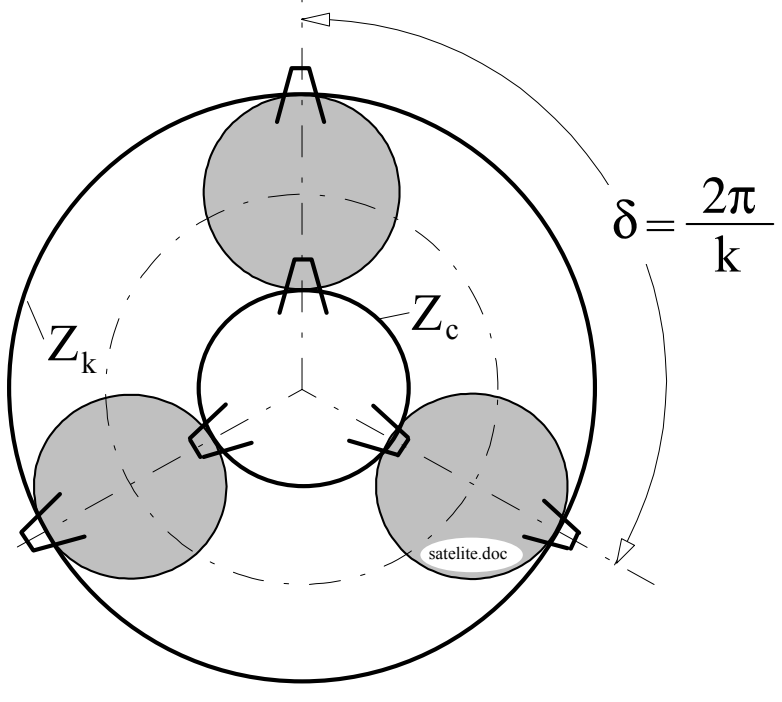

Rys. 4. Schemat rozmieszczenia satelitów w przekładni planetarnej [2].

Aby przekładnia planetarna dała się zmontować, powinna mieć jednakową podziałkę kątową $\delta$ rozmieszczenia satelitów, przy czym k oznacza liczbę satelitów na obwodzie przekładni; $\mathrm{k} \geq 2$;

Zarówno w kole koronowym jak i w kole centralnym przekładni planetarnej ogółem musi być conajmniej tyle zębów, mających jednakowe warunki zazębienia, ile jest satelitów. Może być ich także Ckrotnie więcej, przy czym $\mathrm{C} \in \mathrm{R}^{+}$;

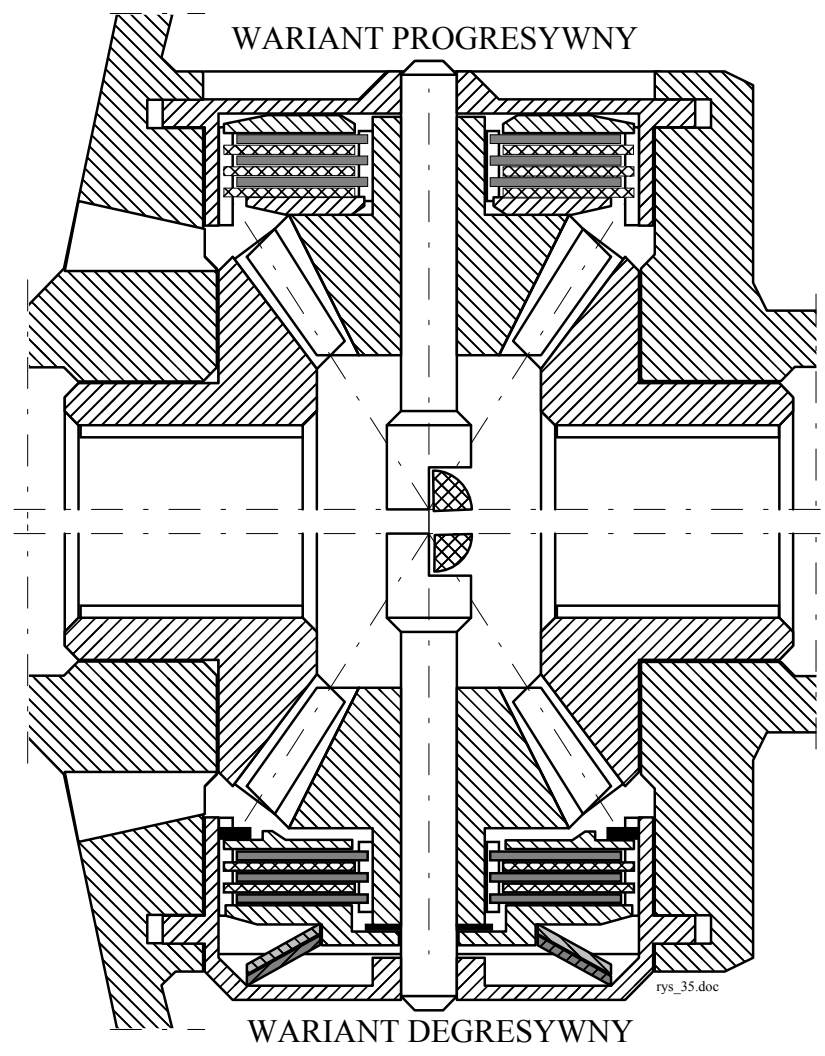

Rys. 5. Przykłady budowy dwóch wariantów rozwiązań 'klasycznego' mechanizmu różnicowego z kołami stożkowymi: u góry - o tarciu wewnętrznym zmiennym progresywnie; $\mathrm{u}$ dołu degresywnie.

$$
\frac{Z_{c}}{k}=C_{c} ; \quad \frac{Z_{K}}{k}=C_{k} ; \quad \text { oraz } \quad \frac{Z_{K}-Z_{c}}{k}>1 ;
$$

Ostatecznie więc możemy napisać następujący warunek konieczny:

$$
Z_{K}-Z_{c}=C \cdot k ;
$$

gdzie: C - dowolna, całkowita, dodatnia liczba rzeczywista; $\mathrm{C} \geq 1$;

Podczas projektowania przekładni jest rzeczą niezbywalną równoczesne spełnienie warunków (8) i (10).

Moment nieczułości różnicowej mechanizmu różnicowego może być stały lub zmienny w funkcji przenoszonego obciążenia trakcyjnego [2]. W tym ostatnim przypadku wyróżnia się narastającą nieczułość różnicową (wariant progresywny) oraz malejącą (wariant degresywny). Budowę poszczególnych wariantów mechanizmów różnicowych i ich ogólne charakterystyki techniczne zilustrowano rysunkami 5, 6 i 7.

Przekładnia planetarno - różnicowa [3] (wg patentu AdTranz), dość łatwo może być wyposażona dodatkowo $\mathrm{w}$ wewnętrzne sprzęgło przeciążeniowe i zastosowana $\mathrm{w}$ układach napędu tramwajów niskopodłogowych przeznaczonych do ruchu miejskiego w hukach toru o małych promieniach krzywizny. Wewnętrzne sprzęgło przeciążeniowe blokuje względne ruchy obrotowe obydwóch półosi, dzięki czemu podczas ruchu tramwaju w torze prostym koła jezdne sa kinematycznie sprzężone podobnie jak w klasycznym zestawie pojazdu szynowego. Natomiast w łuku o małym promieniu krzywizny toru koło zewnętrzne ma moment napędowy zmniejszony w stosunku do koła wewnętrznego o wartość momentu sprzężenia międzyosiowego. Efektywność trakcyjna takiego zestawu $\mathrm{w}$ łuku (w porównaniu do ruchu w torze prostym) jest zmniejszona zależnie od wartości momentu blokującego, pochodzącego od sprzęła przeciążeniowego. Jednak warunki pracy takiego zestawu $\mathrm{w}$ huku sa znacznie lepsze niż przy kołach sprzężonych na sztywno. Przede wszystkim zapobiega się występowaniu pasożytniczych sił ujemnych na obwodzie kół jezdnych [1], co daje $\mathrm{E}_{\mathrm{TZ}} \geq 0,5$.

Przekładnia bez strefy nieczułości różnicowej nie nadaje się do pojazdu szynowego.

Jak wyżej wspomniano, w napędzie AdTranz, pomiędzy półosiami mechanizmu różnicowego a osią kół jezdnych występuje redukcyjna przekładnia zębata o przełożeniu ,i”. Charakterystyka śladowej 'nieczułości różnicowej' fizycznego mechanizmu nie jest znana. Traktując jednak moment nieczułości różnicowej $\mathrm{M}_{\mathrm{TO}}$ mechanizmu różnicowego jako znany, moment nieczułości różnicowej na kołach zestawu wyniesie:

$$
M_{T Z}=M_{T O} \cdot i
$$


W takim przypadku siły obwodowe na kołach będą się różnić o wartość $\Delta \mathrm{F}$.

$$
\Delta F=\frac{2 M_{T O} \cdot i}{R}
$$

Zaś współczynnik efektywności trakcyjnej wyrazi się następująco:

$$
E_{T Z}=1-\frac{\Delta F}{Q_{Z} \cdot \psi(V)}
$$

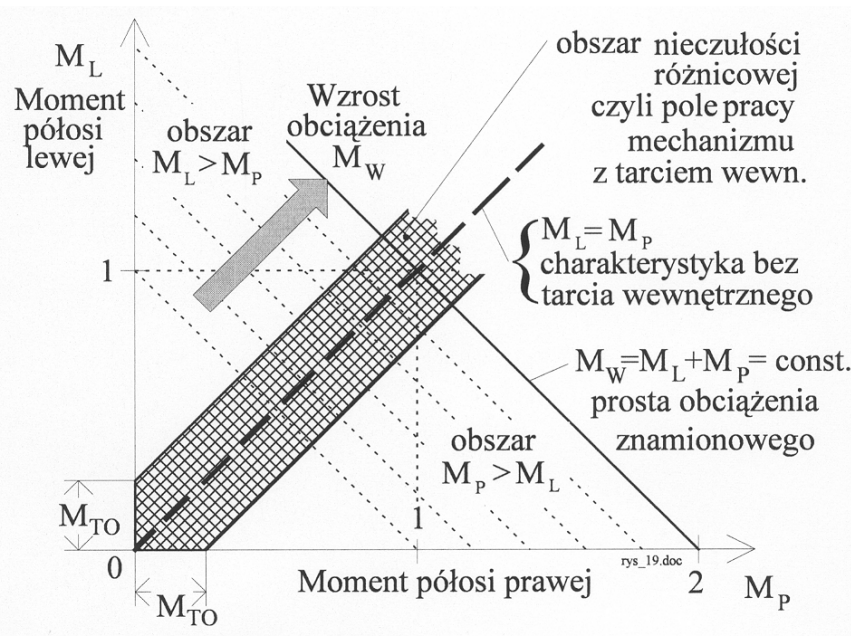

Rys. 6. Charakterystyka mechanizmu różnicowego symetrycznego $\mathrm{z}$ więzami ciernymi na półosiach o stałej wartości momentu nieczułości różnicowej [2].
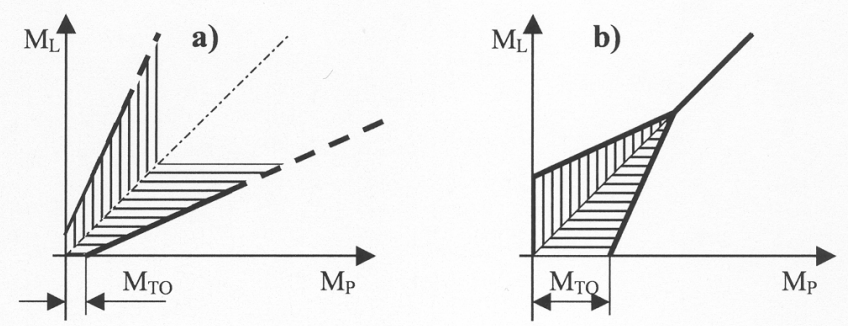

Rys. 7. Charakterystyki tarcia wewnętrznego zależne od obciążenia panującego w mechanizmie różnicowym a) progresywna, b) degresywna.

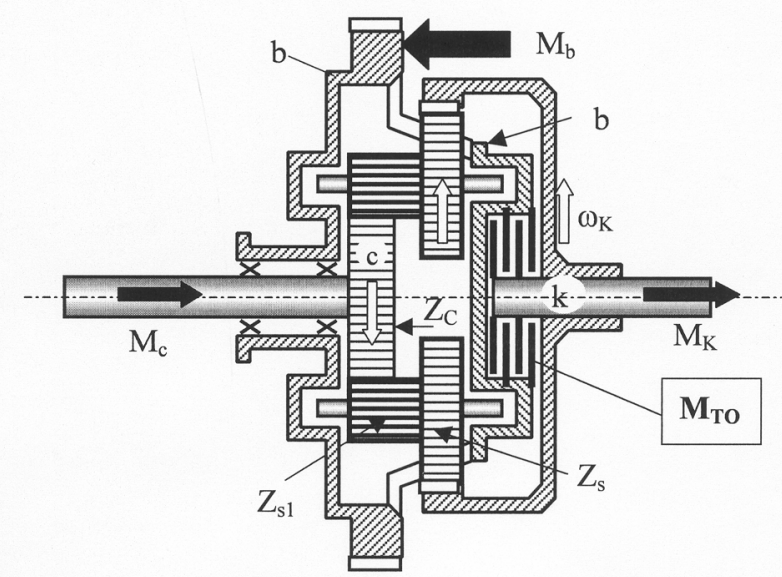

Rys. 8. Schemat przekładni planetarno - różnicowej AdTranz ze sprzęgłem ciernym o stałej nieczułości różnicowej $\mathrm{M}_{\mathrm{TO}}$ według rys. 6.

\section{Podsumowanie i wnioski praktyczne}

1. Przy osadzeniu mechanizmu różnicowego (z odpowiednio dobranym momentem tarcia wewnętrznego o charakterystyce tarcia suchego) bezpośrednio na osi zestawu kół tramwajowych lub na osi zastępczej, sprzęgającej kontur adhezyjny, podczas ruchu w torze prostym zestaw zachowuje się tak, jak zestaw klasyczny. Zatem stabilne prowadzenie zestawu w torze prostym odbywa się dzięki odpowiednim różnicom sił podłużnych pomiędzy kołami i szynami po obydwóch stronach pojazdu, w ramach odpowiednio dobranej nieczułości różnicowej mechanizmu sprzęgającego kontur adhezyjny [2].

2. Przy zastosowaniu mechanizmu różnicowego (o odpowiednio dobranej charakterystyce 'suchego' tarcia wewnętrznego) na osi zestawu kół tramwajowych, podczas trakcyjnego ruchu pojazdu w luku o małym promieniu, różnica sił pociagowych na kołach jest określona przez (stały lub sterowany) moment nieczułości różnicowej pomiędzy „półosiami” tego mechanizmu różnicowego, dzięki czemu uzyskuje się odpowiednią efektywność trakcyjną w łuku toru o małym promieniu (na przykład w miastach zabytkowych).

3. Badanie podłużnej (płaskiej) dynamiki trakcyjnej całego pojazdu i dynamiki układów napędowych najkorzystniej powinno być prowadzone łącznie.

4. Przekładnia AdTranz bez strefy nieczułości różnicowej nie powinna być stosowana w tramwajach.

\section{Przykład obliczeniowy (techniczny):}

Wyznaczenie drogi przejazdu klasycznego zestawu w torze prostym, niezbędnej dla całkowitego odprężenia maksymalnego skręcenia zestawu (ograniczonego silami przyczepności). W przykładzie m.in. wykorzystano teorię podaną $w$ pracy [1].

Rozważymy ruch w łuku zestawu kół zespołu trakcyjnego o następujących wartościach parametrów:

- Nacisk koła na szynę Q=5·10 $[\mathrm{N}]$;

- Rozstaw szyn s=1,5 [m];

- Promień okręgów tocznych $\mathrm{R}=0,5$ [m];

- Średnica osi pomiędzy kołami zestawu d=0,16 [m];

- Moduł sprężystości postaciowej dla stali $\mathrm{G}=8,085$. $10^{10}\left[\mathrm{~N} / \mathrm{m}^{2}\right]$

- Prędkość jazdy zestawu w torze $\mathrm{V}=10[\mathrm{~m} / \mathrm{s}]$;

- Promień łuku $\rho=$ const., możemy traktować jako skokowo zmienny parametr.

Obliczamy kolejno:

Współczynnik przyczepności według Andrewsa:

$$
\Psi(\mathrm{V})=\frac{0,33}{1+0,0288 \cdot \mathrm{V}} ; \quad \Psi_{10}=0,2562 ;
$$

Współczynnik "c" w uproszczonym wzorze Cartera:

$$
\mathrm{c}=70835 \sqrt{\mathrm{Q} \cdot \mathrm{R}} ; \quad \mathrm{c}=1,12 \cdot 10^{7}[\mathrm{~N}] ;
$$


Maksymalna wartość momentu skręcającego w osi zestawu, na granicy przyczepności, przy zadanej prędkości $\mathrm{V}$, wynosi:

$$
\mathrm{M}_{\text {max }}=\mathrm{Q} \cdot \mathrm{R} \cdot \Psi_{10}=5 \cdot 10^{4} \cdot 0,5 \cdot 0,2562=6405[\mathrm{Nm}] ;
$$

Sztywność skrętna osi zestawu wynosi:

$$
\boldsymbol{\aleph}=\frac{\pi \cdot d^{4} \cdot G}{32 \cdot s} ; \quad \boldsymbol{\aleph}=3,467 \cdot 10^{6}\left[\frac{\mathrm{Nm}}{\mathrm{rad}}\right]
$$

Maksymalny kąt skręcenia osi zestawu (w opisanych warunkach pracy) wynosi:

$$
\Delta \Phi_{\max }=\frac{\mathrm{M}_{\max }}{\mathrm{N}} ; \quad \Delta \Phi_{\max }=0,001847[\mathrm{rad}] ;
$$

Maksymalny (bezwzględny) przyrost promienia trakcyjnego $\Delta \mathrm{R}$ wynosi:

$$
\left|\Delta \mathrm{R}_{\max }\right|=\frac{1}{\mathrm{c}} \mathrm{Q} \cdot \mathrm{R} \cdot \Psi_{10} ; \quad\left|\Delta \mathrm{R}_{\max }\right|=5,718 \cdot 10^{-4}[\mathrm{~m}] ;
$$

Droga przejazdu zestawu po prostej, niezbędna dla całkowitego odprężenia maksymalnego skręcenia zestawu klasycznego, wynosiłaby:

$$
\mathrm{L}=\Delta \Phi_{\max } \frac{\mathrm{R}^{2}}{\Delta \mathrm{R}} ; \quad \mathrm{L}=0,80754[\mathrm{~m}] ;
$$

Graniczny promień łuku, na którym jest podtrzymywane maksymalne skręcenie osi [zestawu walcowego] przy zadanej prędkości:

$$
\rho_{\text {gran }}=\frac{\mathrm{R} \cdot \mathrm{s}}{2 \Delta \mathrm{R}_{\max }} ; \rho_{\text {gran }}=656[\mathrm{~m}] ;
$$

Moc tracona na mikropoślizgi graniczne podczas ruchu zestawu w tuku o promieniu $\rho=656[\mathrm{~m}]$ wynosi:

$$
\mathrm{P}=\mathrm{F}_{\text {max }}(\mathrm{V}) \cdot \mathrm{V} \frac{\mathrm{s}}{\rho} ; \quad \mathrm{P}_{656}=5 \cdot 10^{4} \cdot 0,2562 \frac{1,5}{656}=29,29\left[\frac{\mathrm{Nm}}{\mathrm{s}}\right] ;
$$

Moc tracona na mikropoślizgi graniczne podczas ruchu zestawu w łuku o promieniu $\rho=120$ [m] wynosi:

$$
\mathrm{P}_{120}=5 \cdot 10^{4} \cdot 0,2562 \frac{1,5}{120}=160,125\left[\frac{\mathrm{Nm}}{\mathrm{s}}\right]
$$

Z powyższego przykładu wynika dodatkowy istotny wniosek inżynierski, że zmniejszenie w osi momentu skrętnego $\mathrm{M}_{\max }$ do odpowiednio wysterowanej wartości momentu nieczułości różnicowej mechanizmu, zgodnie z powyższym wzorem (*), powoduje skrócenie drogi skrętnego odprężania osi, gdyż liniowo sprężyste odprężanie zachodzi do mniejszej wartości skręcenia osi, zaś większe skręcenia osi są odprężane poślizgowo $\mathrm{w}$ mechanizmie różnicowym. Przy względnie wolnobieżnym ruchu tramwajowym względnie niska wartość momentu nieczułości różnicowej może nie mieć istotnego znaczenia, lecz wymaga to potwierdzenia podczas skrupulatnych badań eksperymentalnych.

\section{LITERATURA.}

[1] Madej J.: Analiza efektywności trakcyjnej zestawu kót pojazdu szynowego w tuku toru o matym promieniu. Pojazdy Szynowe 1/2008

[2] Madej J.: Mechanika Transmisji Momentu Trakcyjnego Oficyna Wydawnicza Politechniki Warszawskiej, Warszawa 2000.

[3] Prospekt firmowy Voith Turbo; voithpl@lodz. pdi.net 